Papers and Proceedings of the Royal Society of Tasmania, Volume 108

(ms. received 12.2 .1974 )

\title{
A SIGHTING OF A LUTH (DERMOCHELYS CORIACEA (L.): CHELONIA) IN BASS STRAIT, TASMANIA
}

by G.F. van Tets, Division of Wildlife Research, CSIRO, G.W. Johnstone and R. Williams, Antarctic Division, Department of Science

At 09.00 h Eastern Daylight Saving Time on 8 December 1973 we observed a 1 arge turtle from the bow of the M.V. NELLA DAN. It was floating at the surface of the water with part of its carapace exposed, and swam slowly southwards out of the ship's path. According to the ship's $10 \mathrm{~g}$, NELLA DAN was at that time in Bass Strait in about 40000's, $147^{\circ} 02^{\prime} \mathrm{E}$, travelling on a course of $309^{\circ}$ west of the Furneaux Group, Tasmania.

We estimated the turtle to be $2 \frac{1}{2} \mathrm{~m}$ long. It was grey and greenish in colour and had three prominent longitudinal dorsal ridges. We saw no indication of large scales on its back. From these characters it was concluded that the turtle was a Luth or Leathery Turtle, Dermochelys coriacea (Linnaeus, 1766). Luths have seven dorsal ridges (De Rooij 1915), but presumably only the median three were visible from above and the other four were obscured by the water.

The Luth occurs throughout the tropical and sub-tropical seas of the world (De Rooij 1915). Occasionally it is also reported from temperate localities, including seven records for Tasmania (Green 1971). Of these two from Fortescue Bay, $43^{\circ} 08^{\prime} s$, $148^{\circ} 00^{\prime} \mathrm{E}$ are the furthest south in Tasmania (Scott and Mollison 1956a and b).

\section{REFERENCES}

De Rooij, N., 1915: The reptiles of the Indo-Australian Archipelago. I. Lacertilia, Chelonia, Emydosaura. Brill, Leiden, $384 \mathrm{pp}$.

Green, R.H., 1971: Sea turtles round Tasmania. Rec. Queen Vic. Mus., 38, 4 pp.

Scott, E.O.G. and Mollison, B.C., 1956a: The Indo-Pacific Loggerhead Turtle in Tasmanian Waters. Nature, 178,372 .

, 1956b: The Indo-Pacific Redbrown Loggerhead Turtle, Caretta caretta gigas Deraniyagala, and the Leathery Turtle, Dermochelys coriacea (Linne) in Tasmanian Waters. Pap. Proc. R. Soc. Tasm., 90, 59-63. 